\title{
Hubungan Antara Usia dan Paritas Ibu Bersalin dengan Bayi Berat Lahir Rendah (BBLR) di Rumah Sakit Islam Siti Khadijah Palembang
}

\author{
Annisa Khoiriah \\ STIK Siti Khadijah Palembang \\ Email: annisakhr_1307@yahoo.co.id
}

\begin{abstract}
The Relation between Age and Maternity Maternity with Low Birth Weight (BBLR) at Siti Khadijah Palembang Islamic Hospital. Low Birth Weight is the birth weight of 1,500-2,500 grams. According to the data of Siti Khadijah Palembang Islamic Hospital in 2016 babies born in LBW from January to September of 2016 both live and die amounted to 172 babies from 1,000 births. The purpose of this study is to know the relationship between maternal age and parity with low birth weight babies at Siti Khadijah Palembang Islamic Hospital in 2016. The method used is an analytical survey with cross sectional approach. The population in this study is all mothers of maternity in Islamic Hospital Siti Khadijah Palembang in 2016 with a sample of 91 people. Based on the univariate analysis of 91 respondents who are not BBLR of $64.8 \%$, low risk as much as $53.8 \%$, low parity $54.8 \%$. The result of bivariate analysis of low risk age that gave birth to LBW was $20,4 \%$, low parity giving birth of LBW by $24 \%$. Age of mother get p value $0,003<0,05$, parity of mother get $p$ value $0,025<0,05$. There is a relationship between maternal age and parity with LBW. For the institution, it is expected that the results of this study can provide benefits for students about the relationship between maternal age and parity with Low Birth Weight. Hospital Parties can provide more intensive information and counseling to the community about the age and parity relationship of delivery mothers with low birth weight babies.
\end{abstract}

Keywords: Age, Parity, Low Birth Weight (LBW)

Abstrak: Hubungan Antara Usia dan Paritas Ibu Bersalin dengan Bayi Berat Lahir Rendah (BBLR) di Rumah Sakit Islam Siti Khadijah Palembang. Bayi Berat Badan Lahir Rendah adalah berat badan bayi lahir 1.500-2.500 gram. Menurut data Rumah Sakit Islam Siti Khadijah Palembang pada tahun 2016 bayi yang dilahirkan BBLR pada bulan Januari sampai September tahun 2016 baik hidup maupun mati berjumlah 172 bayi dari 1.000 kelahiran. Tujuan penelitian ini untuk mengetahui hubungan antara usia dan paritas ibu bersalin dengan bayi berat lahir rendah di Rumah Sakit Islam Siti Khadijah Palembang Tahun 2016. Metode yang digunakan adalah survey analitik dengan pendekatan cross sectional, Populasi dalam penelitian ini adalah seluruh ibu bersalin di Rumah Sakit Islam Siti Khadijah Palembang pada tahun 2016 dengan sampel penelitian berjumlah 91 orang. Berdasarkan analisis univariat dari 91 responden yang tidak BBLR sebanyak $64,8 \%$, resiko rendah sebanyak $53,8 \%$, paritas rendah 54,8\%. Hasil analisis bivariat usia yang resiko rendah yang melahirkan BBLR sebesar 20,4\%, paritas rendah yang melahirkan BBLR sebesar $24 \%$. Usia ibu didapatkan $p$ value $0,003<0,05$, paritas ibu didapatkan $p$ value $0,025<0,05$. Ada hubungan usia dan paritas ibu bersalin dengan BBLR. Bagi institusi diharapkan hasil penelitian ini dapat memberikan manfaat bagi mahasiswa tentang hubungan usia dan paritas ibu bersalin dengan Bayi Berat Lahir Rendah. Pihak Rumah Sakit dapat memberikan informasi dan konseling lebih intensif kepada masyarakat tentang hubungan usia dan paritas ibu bersalin dengan Bayi Berat Lahir Rendah.

Kata kunci: Usia, Paritas, Bayi Berat Lahir Rendah (BBLR)

Bayi Berat Lahir Rendah (BBLR) adalah bayi yang lahir dengan berat badan kurang dari 2.500 gram tanpa memandang masa kehamilan. Dahulu bayi baru lahir dengan berat badan kurang dari 2.500 gram atau sama dengan 2,500 gram disebut prematur. Sedangkan Berat Badan Bayi Normal adalah berat bayi yang lahir dengan berat badan 2.500 gram sampai dengan 4000 gram (Ismawati, 2010).
Menurut Survey Demografi Kesehatan Indonesia (SDKI) tahun 2012 angka kematian BBLR di Indonesia 26,0\% dari 1000 kelahiran hidup. Negara-negara berkembang menduduki angka kelahiran BBLR hingga 15\% sedangkan negara-negara industri maju mempunyai angka kejadian BBLR 7\% (Kemenkes RI, 2012).

Berdasarkan data Dinas Kesehatan Kota Palembang, angka BBLR pada tahun 2014 yaitu 24,4\% dari 1.000 kelahiran, pada tahun 2015 
yaitu 22,3\% dari 1.000 kelahiran,dan pada tahun 2016 yaitu 27,00\% dari 1.000 kelahiran (Dinkes Kota Palembang, 2016).

Ada beberapa faktor resiko yang mempengaruhi BBLR, diantaranya faktor ibu, kehamilan dan faktor janin. Di tinjau dari faktor ibu Salah satunya yaitu usia ibu dan paritas ibu. Faktor usia merekomendasikan bahwa usia yang paling dianggap aman menjalani kehamilan dan persalinan adalah 20 hingga 35 Tahun. Persentase tertinggi bayi dengan berat badan lahir rendah terdapat pada kelompok remaja dan wanita berusia lebih dari 40 tahun. Ibu yang terlalu muda sering kali secara fisik dan emosional belum matang. Sedangkan pada ibu yang sudah tua meskipun mereka berpengalaman, tetapi kondisi tubuh dan kesehatannya sudah mulai menurun sehingga dapat mempengaruhi janin intra uteri dan dapat menyebabkan kelahiran BBLR, (Sistriani, 2008).

Dari hasil studi pendahuluan di Rumah Sakit Islam Siti Khadijah palembang diperoleh data BBLR pada Tahun 2014 bayi yang dilahirkan BBLR baik hidup maupun mati berjumlah $113(11,3 \%)$ dari 1.000 kelahiran, dan pada Tahun 2015 terjadi kenaikan berjumlah 192 bayi $(19,2 \%)$ dari 1.000 kelahiran. Sedangkan Pada Tahun 2016 terjadi penurunan berjumlah 172 bayi $(17,2 \%)$ dari 1.000 kelahiran, namun hal ini masih tetap menjadi perhatian khusus terhadap jumlah angka kematian bayi (AKB) (Medical Record Rumah Sakit Islam Siti Khadijah Palembang, 2017).

\section{METODE}

Jenis penelitian ini mengunakan metode survey analitik Dengan pendekatan "cross sectional" adalah dimana variabel-variabel independen dan variabel dependen dikumpulkan dalam waktu yang bersamaan (Notoatmodjo, 2012).

Populasi dalam penelitian ini adalah seluruh ibu bersalin di Rumah Sakit Islam Siti Khadijah Palembang pada tahun 2016 dengan jumlah besar populasi sebanyak 1000 orang.

Sampel dari penelitian ini adalah sebagian ibu bersalin di Rumah Sakit Islam Siti Khadijah Palembang Tahun 2016 yang berjumlah 91 orang.

Teknik pengambilan sampel yang digunakan dalam penelitian ini adalah dengan menggunakan teknik random sampling. Teknik simpel random sampling adalah pengambilan sampel secara random atau acak. Teknik random sampling ini hanya boleh apabila setiap unit dari populasi mempunyai kesempatan yang sama untuk diseleksi sebagai sampel.

Analisis data yang dilakukan terhadap tiap variabel dari hasil penelitian, variabel independen usia dan paritas dan variabel dependen bayi berat lahir rendah yang ditampilkan dalam bentuk tabel (Hidayat, 2010).

\section{HASIL}

\section{A. ANALISIS UNIVARIAT}

\section{Bayi Berat Lahir Rendah (BBLR)}

Tabel 1. Distribusi Frekuensi Responden dengan Bayi Berat Lahir Rendah (BBLR)

\begin{tabular}{lrr}
\hline BBLR & Frek & \% \\
\hline Ya & 32 & 35.2 \\
\hline Tidak & 59 & 64.8 \\
\hline Jumlah & 91 & 100 \\
\hline
\end{tabular}

Berdasarkan tabel di atas menunjukkan bahwa dari 91 responden, yang mengalami Bayi Berat Lahir Rendah (BBLR) sebanyak 32 responden $(35,2 \%)$, lebih rendah dari yang tidak mengalami bayi berat lahir rendah sebanyak 59 responden $(64,8 \%)$.

\section{Usia}

Tabel 2. Distribusi Frekuensi Usia Ibu Bersalin

\begin{tabular}{lrc}
\hline \multicolumn{1}{c}{ Usia } & Frek & \% \\
\hline Resiko Tinggi & 42 & 46.2 \\
\hline Resiko Rendah & 49 & 53.8 \\
\hline Jumlah & 91 & 100 \\
\hline
\end{tabular}

Berdasarkan tabel di atas menunjukkan bahwa dari 91 responden, yang memiliki usia resiko tinggi sebanyak 42 responden $(46,2 \%)$, lebih rendah dari ibu dengan usia resiko rendah sebanyak 49 responden $(53,8 \%)$.

\section{Paritas}

Paritas ibu bersalin dalam penelitian ini dikelompokkan menjadi 2 (dua) kategori, yaitu paritas rendah (bila paritas ibu $\leq 3$ orang anak) dan paritas tinggi (bila paritas ibu $>3$ orang anak). Untuk lebih jelas dapat dilihat pada tabel berikut: 
Tabel 3. Distribusi Frekuensi Paritas Ibu Bersalin

\begin{tabular}{lrr}
\hline \multicolumn{1}{c}{ Paritas } & Frek & \% \\
\hline Paritas Tinggi & 41 & 45.1 \\
\hline Paritas Rendah & 50 & 54.9 \\
\hline Jumlah & 91 & 100 \\
\hline
\end{tabular}

Berdasarkan tabel di atas menunjukkan bahwa dari 91 responden, yang memiliki paritas tinggi sebanyak 41 responden $(45,1 \%)$, lebih rendah dari ibu yang memiliki paritas rendah sebanyak 50 responden $(54,9 \%)$.

\section{B. ANALISIS BIVARIAT}

\section{Hubungan antara Usia ibu Bersalin dengan Bayi Berat Lahir Rendah (BBLR)}

Tabel 4. Hubungan Usia Ibu Bersalin Dengan Bayi Berat Lahir Rendah (BBLR)

\begin{tabular}{lcccccc}
\hline \multirow{2}{*}{ Usia } & \multicolumn{4}{c}{ BBLR } & \multicolumn{2}{c}{ Total } \\
\cline { 2 - 7 } & \multicolumn{2}{c}{ Ya } & \multicolumn{2}{c}{ Tidak } & n & \% \\
\cline { 2 - 7 } & $\mathbf{n}$ & $\mathbf{\%}$ & $\mathbf{n}$ & $\%$ & & \\
\hline $\begin{array}{l}\text { Resiko } \\
\text { Tinggi }\end{array}$ & 22 & 52.4 & 20 & 47.6 & 42 & 100 \\
\hline $\begin{array}{l}\text { Resiko } \\
\text { Rendah }\end{array}$ & 10 & 20.4 & 39 & 79.6 & 49 & 100 \\
\hline Jumlah & 32 & 35.2 & 59 & 64.8 & 91 & 100 \\
\hline$p$-value & $=0.003$ & \multicolumn{5}{c}{ Odd Ratio $=4.290$} \\
\hline
\end{tabular}

Berdasarkan tabel di atas menunjukkan dari 42 responden dengan usia resiko tinggi, yang mengalami bayi berat lahir rendah sebanyak 22 responden $(52,4 \%)$, lebih besar dibandingkan dari 49 responden dengan usia resiko rendah, yang mengalami bayi berat lahir rendah sebanyak 10 responden $(20.4 \%)$.

Hasil uji Chi-square menunjukkan $\rho$ value $=(0,003) \leq \alpha(0,05)$, yang berarti ada hubungan yang bermakna antara usia ibu dengan kejadian bayi berat lahir rendah. Sehingga hipotesis yang menyatakan ada hubungan antara usia ibu dengan kejadian bayi berat lahir rendah di Rumah Sakit Islam Siti Khadijah Palembang Tahun 2017, diterima secara statistik. Nilai odd ratio $=4,290$ yang berarti responden yang umur beresiko berpeluang 4,290 kali lebih besar terjadinya bayi berat lahir rendah dibandingkan usia yang tidak beresiko.
2. Hubungan antara Paritas Ibu Bersalin dengan Bayi Berat Lahir Rendah (BBLR)

Tabel 5. Hubungan Antara Paritas Ibu Bersalin dengan Bayi Berat Lahir Rendah

\begin{tabular}{|c|c|c|c|c|c|c|}
\hline \multirow{3}{*}{ Paritas } & \multicolumn{4}{|c|}{ BBLR } & \multicolumn{2}{|c|}{ Total } \\
\hline & \multicolumn{2}{|c|}{ Ya } & \multicolumn{2}{|c|}{ Tidak } & \multirow[b]{2}{*}{$\mathbf{n}$} & \multirow{2}{*}{$\%$} \\
\hline & $\mathbf{n}$ & $\%$ & $\mathbf{n}$ & $\%$ & & \\
\hline Paritas Tinggi & 20 & 48.8 & 21 & 51.2 & 41 & 100 \\
\hline Paritas Rendah & 12 & 24.0 & 38 & 76.0 & 50 & 100 \\
\hline Jumlah & 32 & 35.2 & 59 & 64.8 & 91 & 100 \\
\hline$p$ value $=0.025$ & Odd & Ratio & 3.01 & & & \\
\hline
\end{tabular}

Berdasarkan tabel 5 di atas menunjukkan dari 41 responden dengan paritas tinggi, yang mengalami bayi berat lahir rendah sebanyak 20 responden (48,8\%), lebih besar dibandingkan dari 50 responden dengan paritas rendah yang mengalami bayi berat lahir rendah sebanyak 12 responden $(24,0 \%)$.

Hasil uji Chi-square menunjukkan $\rho$ value $=(0,025) \leq \alpha(0,05)$, yang berarti ada hubungan bermakna antara paritas ibu bersalin dengan kejadian bayi berat lahir rendah. Sehingga hipotesis yang menyatakan ada hubungan antara paritas ibu bersalin dengan bayi berat lahir rendah di Rumah Sakit Islam Siti Khadijah Palembang Tahun 2017, diterima secara statistik. Nilai odd ratio=3,016 yang berarti responden yang paritas tinggi berpeluang 3,016 kali lebih besar untuk terjadi bayi berat lahir rendah dibandingkan paritas rendah.

\section{PEMBAHASAN}

\section{Hubungan antara Usia Ibu dengan Bayi Berat Lahir Rendah (BBLR)}

Berdasarkan hasil penelitian ini didapatkan bahwa dari 91 responden yang memiliki usia resiko tinggi sebanyak 42 responden $(46,2 \%)$, lebih rendah dari usia resiko rendah sebanyak 49 responden $(53,8 \%)$.

Berdasarkan hasil penelitian bivariat ini menunjukkan dari 42 responden dengan usia resiko tinggi, yang mengalami bayi berat lahir rendah sebanyak 22 responden $(52,4 \%)$, lebih besar dibandingkan dari 49 responden dengan usia resiko rendah, yang mengalami bayi berat lahir rendah sebanyak 10 responden $(20,4 \%)$, dari hasil uji statistik chi-square didapatkan $\rho$ value $(0,003) \leq(0,05)$. Hal ini menunjukkan bahwa secara setatistik ada hubungan yang bermakna antara usia ibu dengan Bayi Berat Lahir Rendah (BBLR), sehingga hipotesis yang menyatakan 
ada hubungan usia ibu dengan kejadian (BBLR) terbukti.

Hasil penelitian ini sejalan dengan hasil penelitian yang dilakukan oleh Setyowati (2007) dengan judul hubungan antara pendidikan dan umur ibu bersalin dengan kejadian berat badan lahir rendah (BBLR) di RSUD dr. Moch. Soewandhie surabaya tahun 2007. Hasil analisis bivariat di dapatkan ibu yang memiliki umur resiko tinggi 99 responden dan pada ibu yang resiko rendah 88 responden, $\rho$ value yang didapatkan dari hasil analisis ini adalah 0,001. Hasil analisis tersebut menunjukkan bahwa ada hubungan umur ibu dengan kejadian Bayi Berat lahir rendah (BBLR).

Hasil penelitian ini juga sejalan dengan hasil penelitian yang dilakukan Alya (2014) dengan Judul faktor-faktor yang berhubungan dengan Bayi Berat Lahir Rendah (BBLR) di RSIA Bandah Aceh Tahun 2014. Hasil analisis bivariat didapatkan ibu yang memiliki umur resiko tinggi $29 \mathrm{ibu}(24,6 \%)$ responden dan pada ibu yang resiko rendah 30 ibu $(25,4 \%)$ responden, $\rho$ value yang didapatkan dari hasil analisa ini adalah 0,000. Hasil analisa tersebut menunjukkan bahwa ada hubungan umur ibu dengan kejadian Bayi Berat Lahir Rendah (BBLR).

Pengaruh usia ibu terhadap kejadian BBLR merupakan faktor resiko tinggi, karena wanita yang hamil usia dibawah 20 tahun perkembangan organ-organ reproduksi dan fungsi fisiologisnya belum optimal. Selain itu emosi dan kejiwaannnya belum cukup matang sehingga pada saat kehamilan ibu tersebut belum dapat menanggapi kehamilannya secara sempurna dan sering terjadi komplikasi. Sedangkan kehamilan diatas usia 35 tahun juga tidak dianjurkan, mengingat mulai usia ini sering muncul penyakit seperti hipertensi, tumor jinak, dan penyakit degeneratif lainnya. Dalam peroses persalinan sendiri, kehamilan diusia 35 tahun ke atas akan menghadapi kesulitan akibat lemahnya kontraksi rahim serta timbul kelainan pada tulang panggul tengah (Notobroto, 2007).

Dari uraian diatas peneliti berasumsi bahwa usia dapat mempengaruhi ibu untuk melahirkan bayi BBLR karena pada saat usia ibu $<20$ tahun organ-organ reproduksi dan fungsi fisiologisnya belum optimal, selain itu emosi dan kejiwaannya belum cukup matang sehingga saat hamil ibu tidak bisa menanggapi kehamilannya secara sempurna. Kemudian pada ibu yang melahirkan pada usia > 35 tahun, juga beresiko untuk melahirkan bayi BBLR karena ibu sudah lebih rentan mengalami penyakit degeneratif dan kondisi tubuh ibu juga menurun.

\section{Hubungan antara Paritas dengan Bayi Berat Lahir Rendah}

Berdasarkan hasil penelitian univariat ini dapatkan bahwa dari 91 responden yang memiliki paritas tinggi sebanyak 41 responden $(45,1 \%)$, lebih rendah dari paritas rendah sebanyak 50 responden $(54,9 \%)$.

Berdasarkan hasil penelitian bivariat ini menunjukkan dari 41 responden dengan paritas tinggi, yang mengalami bayi berat lahir rendah sebanyak 20 responden (48,8\%), lebih besar dibandingkan dari 50 responden dengan paritas rendah, yang mengalami bayi berat lahir rendah sebanyak 12 responden $(24,0 \%)$, dari hasil uji statistik chi-square didapatkan $\rho$ value $(0,025) \leq$ $(0,05)$. Hal ini menunjukkan bahwa secara statistik ada hubungan yang bermakna antara paritas dengan kejadian bayi berat lahir rendah, sehingga hipotesis yang menyatakan ada hubungan paritas dengan Bayi Berat Lahir Rendah (BBLR) terbukti.

Pengaruh paritas terhadap kejadian BBLR. Ibu yang pernah melahirkan anak lebih dari tiga kali beresiko melahirkan bayi BBLR, hal ini di karenakan keadaan rahim biasanya sudah lemah dikarenakan oleh alat-alat reproduksi yang sudah menurun sehingga sel-sel otot mulai melemah dan bagian tubuh lainnya sudah menurun sehingga dapat menyebabkan dan meningkatkan kejadian BBLR. Dari hasil penelitian menunjukkan bahwa paritas merupakan faktor resiko tinggi penyebab BBLR, dimana ibu dengan paritas $>3$ anak akan beresiko 2 kali melahirkan BBLR (Zaenab, 2006).

Dari uraian diatas peneliti berasumsi bahwa ibu dengan paritas tinggi dapat mempengaruhi ibu untuk melahirkan bayi BBLR, itu dikarenakan kehamilan yang berulang-ulang akan menyebabkan kerusakan pada dinding pembuluh darah uterus, hal ini akan mempengaruhi nutrisi ke janin pada kehamilan selanjutnya sehingga dapat menyebabkan gangguan pertumbuhan janin yang selanjutnya akan melahirkan bayi dengan BBLR.

\section{SIMPULAN}

Dari hasil penelitian yang telah dilakukan di Rumah Sakit Islam Siti Khadijah Palembang Tahun 2017 dapat di simpulkan bahwa :

1. Distribusi frekuensi Bayi Berat Lahir Rendah (BBLR) sebanyak 32 responden, yang tidak mengalami bayi berat lahir rendah sebanyak 59 responden. 
2. Distribusi frekuensi bahwa usia ibu dengan resiko tinggi sebanyak 42 responden, resiko rendah sebanyak 49 responden.

3. Distribusi frekuensi bahwa paritas ibu dengan paritas tinggi sebanyak 41 responden, paritas ibu dengan paritas rendah sebanyak 50 responden.

4. Ada hubungan yang bermakna antara usia dengan kejadian bayi berat lahir rendah, dengan $\rho$ value 0,003 .

\section{DAFTAR PUSTAKA}

Alya, D. I. A. N., \& U'BUDIYAH, S. T. I. K. 2014. Faktor-faktor yang berhubungan dengan Bayi Berat Lahir Rendah (BBLR) di Rumah Sakit Ibu dan Anak Banda Aceh Tahun 2013. Skripsi. Program Studi Diploma IV Kebidanan STIKes Ubudiyah: Banda Aceh.

Dinas Kesehatan kota Palembang. 2016. Profil Kesehatan Kabupaten Kota Palembang 2014. Palembang.

Dinas Kesehatan Kota Palembang. 2016. Evaluasi Subdin PMK Dinas Kesehatan Kota Palembang 2016, Palembang. http://dinkes.palembang.go.id

Hidayat. 2010. Teknik Penulisan Ilmiah. Jakarta: Selemba Medika.

Ismawati., Cahyo. 2010. Berat Badan Lahir Rendah. Yogyakarta: Nuha Medika.

Kementerian Kesehatan RI. 2012. Kesehatan Tahun 2012 Jakarta: Pusat Data dan Informasi.
5. Ada hubungan yang bermakna antara paritas dengan kejadian bayi berat lahir rendah, dengan $\rho$ value 0,025 .

\section{SARAN}

Pihak Rumah Sakit perlu memberikan informasi dan konseling lebih intensif kepada masyarakat tentang hubungan usia dan paritas ibu bersalin dengan Bayi Berat Lahir Rendah.

Notoatmojo. 2012. Metode Penelitian Kesehatan. Jakarta: Rineka Cipta.

Notobroto, Ika. 2007. Bayi dengan BBLR. Yogyakarta: Nuha Medika.

Rumah Sakit Islam Siti Khadijah Palembang. 2017. Medical Record Rumah Sakit Islam Siti Khadijah Palembang.

Sistriani, C, Astuti. 2008. Faktor Maternal dan Kualitas Pelayanan Antenatal yang beresiko terhadap Kejadian Berat Badan Lahir Rendah (BBLR) Studi pada ibu yang periksa Hamil ke Tenaga Kesehatan dan Melahirkan di RSUD Banyumas. Tesis FKM. Universitas Diponegoro.

Zaenab. 2006. Beberapa Faktor resiko kejadian BBLR di Rumah Sakit Al Fatah Ambon Periode januari-desember. Skripsi. RS Al Fatah Ambon. 